\title{
ПРИДАТНІСТЬ ПОКАЗНИКА ПРЕВАЛЕНТНОСТІ ВІЛ-ІНФЕКЦІЇ СЕРЕД ВАГІТНИХ ДЛЯ ОЦІНЮВАННЯ ПОШИРЕНОСТІ ВІЛ СЕРЕД ЗАГАЛЬНОГО НАСЕЛЕННЯ УКРАЇНИ
}

\author{
Національний медичний університет ім. О.О. Богомольця, м. Київ
}

Оцінка загального показника поширеності ВІЛ-інфрекції серед жіночого населення репродуктивного віку у разі використання нестандартизованих за віковою структурою показників превалентності ВІЛ-інорекції серед вагітних некоректна і завищена (різниця із стандартизованими показниками в окремі роки сягав 37,7\%).

Ключові слова: ВІЛ-інфрекція, вагітні, показник превалентності.

Від самого початку виникнення пандемії ВІЛ-інфекції належним чином не вирішене питання адекватного кількісного оцінювання проявів епідемічного процесу цієї інсрекції. Вимірювання поширеності (превалентності) ВІЛ-інфекції здійснюється за результатами тестування зразків крові на біомаркери ВІЛ серед вагітних та населення груп підвищеного ризику. На підставі цих даних розраховується оціночна кількість ВІЛ-інфрікованого загального населення та визначається стадія епідемії ВІЛ-інфекції. В Україні, за офріційними даними, за період 2005-2013 рр. має місце суттєве зменшення (з 0,6 до 0,39 \%) показника поширеності ВІЛ-інфекції серед вагітних. Можливими причинами цього можуть бути як дійсне зменшення темпів поширення епідемії, так і (або) похибки у вимірюванні показника превалентності, який $є$ нестандартизованим у відповідності з віковою структурою вагітних по відношенню до вікової структури всього дорослого репродуктивного жіночого населення. Показник поширеності ВІЛ-інфрекції серед вагітних, що розраховується за результатами серологічних досліджень цього контингенту населення, не зовсім точно відображає рівень поширеності ВІЛ-інфекції серед всього жіночого населення, оскільки у віковій структурі вагітних переважають більш молоді жінки, ніж серед загального жіночого населення. На жінок у віці до 30 років в Україні припадає не менше 70 \% всіх вагітностей, які завершуються народженням дитини. Стандартизація показника поширеності ВІЛ-інфекції серед вагітних дозволяє розрахувати останній таким чином, що його значення буде відповідати загальній віковій структурі дорослого жіночого населення.

Мета роботи - розрахувати стандартизовані показники поширеності ВІЛ-інсрекції серед вагітних України у 2005-2013 рр. для визначення й оцінки превалентності ВІЛінфрекції серед сукупного жіночого населення та загального населення, яке не належить до груп підвищеного ризику щодо зараження та захворювання на ВІЛ-інфрекцію.

Матеріали та методи. Для розрахунків використано дані сероепідмоніторингу на ВІЛ-інсекцію вагітних (код 109.1) у 2005-2013 рр., віковий розподіл вагітних, які народили дитину, та іноормацію про віковий розподіл жінок віком 15-49 років, у яких виявлено ВІЛ-інфрекцію (бюлетені «ВІЛ-інфекція в Україні» та неопубліковані дані служби соцзахворювань України). Розрахунки проводилися методом непрямої стандартизації.

Результати та обговорення. Стандартизовані показники превалентності по всіх роках за вказаний період, як і очікувалося, виявилися меншими за нестандартизовані (в окремі роки різниця досягала 37,7 \%), що, ймовірно, вказує на завищену оцінку загального показника поширеності ВІЛ-інфекції серед жіночого населення у разі використання нестандартизованих показників. У будь-якому разі наявні дані вказують на те, що і нестандартизовані, і стандартизовані показники менші за показник 1 \%. Таким чином, можна стверджувати про наявність концентрованої стадії епідемії ВІЛ-інфрекції в Україні, але питання щодо реального показника превалентності ВІЛ-інфекції серед загального населення України та оціночної кількості ВІЛ-інфрікованих потребує подальшого вивчення та уточнення.

Таким чином, нестандартизовані за віковою структурою показники превалентності ВІЛ-інфекції серед вагітних не можуть безпосередньо екстраполюватися на все населення України, оскільки нестандартизовані показники менш точно відображають поширеність ВІЛ-інфекції навіть серед сукупного дорослого жіночого населення репродуктивного віку. 


\section{PREVALENT INDEX OF HIV AMONG PREGNANT FOR EVALUATION PREVALENCE}

H.A. Mokhort, I.P. Kolesnikova

SUMMARY. Evaluation of the overall prevalence of HIV among the female population of reproductive age in the case of non-standardized for age structure indicators prevalentnosti HIV infection among pregnant incorrect and exaggerated (the difference with standardized indicators in some years to $37,7 \%$ ).

Key words: HIV-infection, pregnant, prevalence index.

Отримано 16.11.2015 p.

\title{
І.П. Колеснікова, Т.В. Петрусевич, О.В. Зубленко СТАВЛЕННЯ МАЙБУТНІХ ЛІКАРІВ ДО ЛЮДЕЙ, ЯКІ ЖИВУТЬ 3 ВІЛ
}

\author{
Національний медичний університет ім. О.О. Богомольця, м. Київ
}

\begin{abstract}
Формування толерантного ставлення до людей, які живуть з ВІЛ, у студентів вищих медичних навчальних закладів є дуже важливим аспектом роботи майбутніх лікарів у подоланні наслідків епідемії ВІЛ. Майже половина студентів (48,8 \%) ставляться до таких людей упереджено, тому потрібно обирати правильні стратегії медичних освітніх програм.
\end{abstract}

Ключові слова: люди, які живуть з ВІЛ, ставлення лікарів.

Толерантне ставлення студентів медичних навчальних закладів як майбутніх лікарів $є$ запорукою для подальшого успіху лікування та збереження якості життя людей, які живуть 3 ВІЛ (ЛЖВ). Стигма та дискримінація, які обумовлені ВІЛ-статусом, не тільки суттєво обмежують доступ людей, які живуть з ВІЛ, до медичних послуг, але й ускладнюють профрілактику розповсюдження ВІЛ та виявлення нових випадків інфікування. Дані дослідження, проведеного в Республіці Білорусь в 2011 р., свідчать про те, що 30,8 \% медичних працівників не мали бажання працювати з ВІЛінфрікованими пацієнтами, а 11,8 \% відчували психологічний дискоморорт при роботі з такими пацієнтами; $20 \%$ студентів-випускників мали труднощі при визначенні свого ставлення до ЛЖВ. Небажання надавати медичну допомогу ВІЛ-позитивним пацієнтам у маргінальних групах вислови- ли 26,4-71,9 \% студентів-медиків у Казанському медичному університеті (Bikmukhametov D.A. et al., 2012). Більш ніж п'ята частина студентів-медиків в Англії та Хорватії вважали, що лікарі мають право відмовитися від лікування ЛЖВ (Evans J.K. et al., 1993; Tesic V. et al., 2006). Близько 10-15 \% студентів-медиків одного з медичних ВУЗів Малазії висловили небажання надавати медичні послуги лжВ та більше 70 \% вважали, що пацієнти з ВІл/СНІД мають лікуватись окремо (Chew B. H. et al., 2013).

Для вивчення ставлення до лЖВ у майбутніх лікарів було проведено опитування студентів Національного медичного університету ім. О.О. Богомольця за модифікованими питаннями стандартних опитувальників, які опубліковані у рекомендаціях з проведення періодичних досліджень в межах вивчення поведінки груп населення, які піддаються ризику інфікування ВІЛ, та адаптованих опитувальників Центру з контролю та просрілактики захворювань США. Також були враховані пропозиції «Методичних рекомендацій 3 дослідження толерантного ставлення до людей, що живуть з ВІЛ, як компоненту національної системи моніторингу та оцінки ефективності заходів, що забезпечують контроль за епідемією ВІЛ/СНІД».

Опитування було проведено на кафедрі епідеміології серед студентів 5-го курсу медичних сракультетів при вивченні дисципліни «Епідеміологія». Навчальний план 